\title{
Isu-isu Kontemporer Ekonomi Pancasila
}

\author{
M. Dawam Rahardjo
}

Reformation and it's process shows us that Indonesia has lost it's direction in maintaining economical situation. Pancasila economic system, is still become our economic paradigm, referring to chapter 33 of amended constitution of 1945. Koperasi (corporation) as the pillar for Pancasila economic system, still unable to answer economic challenges for the future. The unclear direction of economic development, actually is caused by the ignorance of people toward ideas which is relevant to be grown in the context of Pancasila economic system. With only catching the surface of this economic system, impossible for Indonesian people to think deeply and maturely toward this economic system itself. Thus, this is the real question which must be addressed in the future coming.

$\mathrm{M}$ asalah yang dihadapi oleh Sistem Ekonomi Pancasila (SEP), sebagai gagasan, barangkali akan lebih bisa dipahami dengan membandingkannya dengan kasus gagasan lain yang serupa. Dalam hal ini akan dibandingkan dengan gagasan "Ekonomi Pasar Sosial" (EPS) atau "Social Market Economy" (SME) dalam perkembangan dan pembangunan ekonomi di negara Republik Federal Jerman (Jerman Barat sebelum unifikasi), tempat gagasan tersebut lahir.

\section{Sejarah Pemikiran SEP dan EPS}

Dalam penjelasannya mengenai EPS dalam suatu seminar April 1995, Prof. Jochen Roepke juga membandingkan EPS dengan SEP untuk Indonesia. ${ }^{1}$ Sebagaimana SEP, EPS adalah sebuah gagasan mengenai sistem ekonomi. Menurut Gernot Gutmann, gagasan EPS secara mendalam mengakar pada konsep etika Kristen, baik dari pemikiran Katholik maupun aliran Kristen Protestan Lutheran. EPS adalah sebuah konsep teoritis yang mula-mula dibangun oleh Profesor Alfred Muller-Armack dan kemudian diwujudkan melalui aksi politik menjadi realitas praktis sesudah Perang Dunia II, oleh Ludwig Erhard yang selama beberapa tahun menjadi menteri federal dan kemudian kanselir Republik Federal Jerman. ${ }^{2}$ Sedangkan gagasan Ekonomi

1 Prof. Dr. Jochen Roepke "Ekonomi Pasar Sosial: Resep Bagi Indonesia" dalam buku M. Furqon Alfaruqiy \& M. Soelhi eds. "Relevansi Ekonomi Pasar Sosial bagi Indonesia" \& Konrad Adenaurer-Stiftung Jakarta, 1995. Dalam artikel itu "Ekonomi Pancasila" disebut dua kali, di catatan kali hal 11-1, dari hal. 11-2. Disitu Roepke membandingkan EPS dengan Ekonomi Pancasila.

2 Gernot Gutmann "The Intellectual :Basis and Historical Development of Social Market Economy" dimuat dalam buku Winfried Jung Cel. "Social Market Economy: an Economic System for Developing Countries". Internationales Institut "Konrad AdenauerStiftung". Buku ini mencerminkan pandangan Partai Kristen Demokrat. Jerman Barat terhadap EPS. Disitu antara lain dikatakan bahwa EPS tidak identik dengan "free market economy" maupun aliran "monetarist". 
Pancasila (EP), mula-mula dilontarkan oleh Profesor Emil Salim yang juga beberapa tahun menjabat sebagai wakil ketua Badan Perencanaan Pembangunan (Bappenas) dan menteri di dua departemen, yaitu Departemen Perhubungan dan Departemen Kependudukan dan Lingkungan Hidup. ${ }^{3}$

Walaupun EPS baru dilaksanakan pada masa sesudah PD Il namun gagasan inj sebagaimana diuraikan oleh Prof. Rüdiger Funk, sebenarnya sudah mulai berkembang sebelum PD II atau sesudah PD I, yaitu sejak dasawarsa 30-an. Gagasan itu sendiri berasal dari tiga sumber. Pertama adalah faham NeoLiberalisme yang dikembangkan oleh dua ekonom Jerman, Alexander Rustow dan Wilhelm Roepke. Pada tahun 1932 Rustow mengeluarkan pendapat tentang betapa pentingnya suatu sistem perekonomian bebas, tetapi tidak sebagaimana faham liberalisme klasik yang mendasarkan diri pada prinsip laissez faire, dimana kegiatan ekonomi dikendalikan oleh tangan gaib (invisible hand). Neo-Liberalisme Jerman ini tidak mau disamakan bahkan bertentangan dengan aliran Neo-Klasik dan Libertarian. Berbeda dengan aliran liberal klasik, Roepke justru berpendapat tentang pentingnya peranan pemerintahan yang kuat untuk melindungi pasar dari berbagai kelompok kepentingan (interest group) yang bisa merusak pasar dan keseimbangan sosial. Dengan demikian, Neo-Liberal Jerman ini justru percaya pada peranan "tangan yang nampak" (visible hand). Sumber kedua adalah aliran ekonomi mazhab Freiburg yang muncul pada tahun 1930-an yang dipelopori oleh dua ahli hukum, Franz Bohm dan Hans Grossmann-Doerth dan seorang pakar ekonomi, Walter Eucken yang melahirkan Ordo-Liberalisme. Dan sumber ketiga adalah Etika Sosial Kristen, terutama Etika Sosial Katholik. ${ }^{4}$
Semua pendahulu dari EPS ini mempunyai kesamaan pandangan yang mendasar bahwa Liberalisme abad ke 19 telah menjurus kepada eksploitasi dan hancurnya kemanusiaan serta mendukung struktur kekuasaan yang mengakibatkan ketidak-stabilan ekonomi dan politik. Karena itu, mereka berpendapat bahwa sistem ekonomi pasar itu perlu diatur, suatu pemikiran yang sepintas mengandung kontradiksi. Posisi dasar bersama penganut Neo-Liberalisme dan Ordo-Liberalisme adalah:

- Pembatasan yang ketat terhadap ajaran Liberalisme.

- Kritik radikal terhadap kolektivisme, baik jenis Nazi maupun Komunisme dan Sosialisme

- Sama-sama menyetujui masyarakat dan sistem perekonomian yang liberal murni yang diartikan sebagai "jalan ketiga" antara kedua ekstrim yang dikecam, yaitu antara Liberalisme laissez di satu pihak faire dan Kolektivisme sosialis di lain pihak.

- Sama-sama menuntut suatu kebijaksanaan tatanan ekonomi yang konsekuen. ${ }^{5}$

Untuk itu dibutuhkan suatu pemerintahan atau negara yang kuat dan independen untuk menetapkan kerangka aturan permainan ekonomi serta sasaran-

${ }^{3}$ Tulisan Emil Salim yang pertama berjudul "Sistim Ekonomi Pancasila", dimuat di harian Kompas, 30 Juni, 1966, dimuat kembali dalam buku Hamid Basyaib \& Hamid Abidin eds. "Kembali ke Jalan Lurus: Esai-esai 1966-99, Alvabet, Jakarta, 2000, lihat hal 3-5.

${ }^{4}$ Baca artikel Prof. Rudiger Funk "Model dan Kenyataan Ekonomi Pasar Sosial, Khususnya dipandang dari sudut Kebijakan Persaingan" dalam buku M. Furqon Alfaruqiy \& M. Soelhi, op.cit hal I-6 dan I-8.

${ }^{5}$ Ibid, op.cit hal I-6 dan I-8. 
Pancasila, khususnya berkaitan dengan strategi pembangunan. Sritua Arief banyak membahas isu-isu mengenai hutang luar negeri, penanaman modal asing, peranan IMF dan Bank Dunia yang berusaha mendikte kebijaksanaan ekonomi Indonesia. ${ }^{9}$ Prof. Mubyarto juga membahas beberapa isu kontemporer, misalnya masalah globalisasi, privatisasi dan paham Neo-Liberalisme yang berlawanan dengan prinsip populisme, tantangan otonomi daerah dan ekonomi kerakyatan. ${ }^{10}$

Dalam realisasinya, ESP menghadapi dilema antara menempuh "model sistem" (meminjam istilah Emil Salim) "perencanaan sentral" dan sistem pasar bebas." Menghadapi situasi kehancuran sesudah perang dengan masalah-masalah inflasi (mata uang yang tidak ada harganya), pengangguran, kemiskinan dan kekacauan sosial, negara baru Jerman yang didominasi oleh kekuatan sekutu yang menang perang (AS, Rusia, Inggris dan Prancis) itu terdorong untuk memakai sistem perencanaan sentral. Tapi pada waktu itu birokrasi telah rusak, kekuatan pemerintah dan legitimasi politik sangat lemah, tenaga ahli sangat kurang dan informasi mengenai keadaan ekonomi hampir nihil, sehingga tidak mungkin dibentuk lembaga perencanaan pusat dan jika pun dibentuk tidak bisa melaksanakan tugasnya. Karena itu pilihannya, adalah menyerahkan prakarsa dan keputusan ekonomi (produksi, distribusi dan konsumsi) kepada rakyat. Tapi memampuan rakyat untuk mengambil keputusan juga sangat lemah, karena tidak adanya informasi pasar. Karena itu pilihan tengah-tengahnya, seperti terkandung dalam EPS adalah menepuh sistem pasar bebas dengan dukungan hukum yang disertai dengan kepemimpinan pemerintah yang kuat. Disini, peranan teknokratnegarawan Ludwig Erhard yang muncul memegang tampuk pimpinan pada tahun 1948 , sangat penting. ${ }^{12}$

Sebagaimana di Indonesia pada awal kemerdekaan, Jerman juga sangat dipengaruhi oleh faham sosialisme. Namun pimpinan pemerintahan seperti Erhard pada waktu itu berani menentang arus, yaitu memilih sistem pasar bebas, namun dikawal dengan kebijaksanaan sosial. Faktor lain adalah dukungan kelas buruh pada waktu itu yang sangat mendapat perhatian dari pemerintah melalui kebijaksanaan pasar tenaga kerja, perlindungan kerja, distribusi pendapatan dan pengamanan terhadap risiko kerja serta jaminan sosial yang memang sudah merupakan pandangan kuat sejak di masa Bismark, sebagai perintis sistem jaminan sosial. ${ }^{13}$

Salah satu keistmewaan dari EPS adalah realisasinya yang berkesinambungan dan konsisten, dengan kombinasi komitmen kuat dari rezim yang berkuasa dan dukungan kuat dari rakyat yang sebenarnya juga terdiri dari kekuatan yang beragam, yaitu kekuatan sosial demokrat, kekuatan Kristen (Katholik dan Lutheran) dan kekuatan liberal. Di Indonesia juga terdapat beberapa kekuatan politik, yaitu kaum nasionalis, Islam (dan

9 Baca misalnya Dr. Sritua Arief "Pembangunanisme dan Ekonomi Indonesia: Pemberdayaan Rakyat dalam Arus Globalisasi", Zaman, 1998.

10 Baca misalnya buku Mubyarto "Membangun Sistem Ekonomi" BPEE Yogyakarta, 2000.

"Baca Emil Salim "Sistem Ekonomi dan Ekonomi Indonesia" Lembaga Ekonomi dan Kemasyarakatan Nasional, Majelis IImu Pengetahuan Indonesia, Jakarta, 1965.

12 Prof. Rudiger Funk, op.cit. hal I-8. Erhad menggantikan Konrad Adenauer sebagai Bundeskanzler.

${ }^{13} \mathrm{lbid}$. op.cit hal 1-24. 
sasarannya yang pasti. Liberalisme baru ditopang oleh "segi-tiga ajaib" atau trilogi, yaitu "kebebasan individu" yang dijamin dan dilindungi oleh negara, jaminan sosial masyarakat yang diciptakan melalui kebijaksanaan sosial (social policy) dan pertumbuhan ekonomi yang terkendali. Sasaran kebijaksanaan EPS adalah: stabilitas nilai mata uang, tanpa pengangguran atau kesempatan kerja penuh (full employment), pertumbuhan ekonomi yang wajar dan keseimbangan neraca pembayaran. Sementara itu faham Ordoliberalisme menekankan pada prinsip bahwa negara ditugaskan untuk menyusun kebijaksanaan sosial yang menyeluruh melalui kebijaksanaan distribusi pendapatan dan kekayaan yang aktif guna menghilangkan kesenjangan sosial. Ordo Liberalisme ini juga menekankan adanya jaminan sosial dan proteksi terhadap hak-hak pekerja. Dengan perkataan lain, EPS berusaha mengkaitkan kebebasan pasar dengan keseimbangan sosial. Di bidang sosial, EPS ingin mencapai tiga sasaran makro, yaitu keadilan sosial (social justice), jaminan sosial (social security) dan kemajuan sosial (social progress).

Ketika mulai dilaksanakan, EPS tidak merupakan suatu sistem resmi dan sistem tertutup yang dianut oleh negara. Di Indonesia, pada masa sesudah kemerdekaan, juga tidak pernah disebut SEP, namun dalam UUD 1945 , dicantumkan pasal-pasal yang berkaitan dengan sistem ekonomi yang intinya ditulis dalam pasal 33, dan aspek-aspek lain, yang sifatnya politik dicantumkan pada pasal 23 (mengenai hak budget dewan perwakilan rakyat) dan yang sifatnya sosial tercantum pada pasal-pasal 27 ayat 1 (mengenai kesempatan kerja dan tingkat hidup), dan pasal 34 mengenai jaminan sosial terhadap fakir miskin dan anak-anak terlantar yang menjadi tanggung-jawab negara. Bahkan untuk mewujudkan pasal 34 tersebut dibentuk departemen sosial. Pasal-pasal itulah dan kini rumusan dalam Pembukaaan UUD 1945 yang merupakan nilai-nilai keutamaan (virtue), merupakan dasar-dasar pemikiran mengenai apayang baru pada tahun 1966 dan dikukuhkan kembali pada tahun 1979 disebut oleh Emil Salim sebagai Sistem Ekonomi Pancasila (SEP) ${ }^{6}$

Baik ESP maupun SEP adalah suatu sistem yang terbuka, artinya terbuka bagi gagasan-gagasan baru. Pada tahun 1980 , sejumlah ekonom, terutama dari FE-UGM, menyempurnakan gagasan itu menjadi konsep Ekonomi Pancasila (EP). Pada waktu itu ditambahkan konsep-konsep epistemologi dan aksiologi, terutama oleh Dr. Sarino Mangunpranoto. ${ }^{7}$ Sumbangan pemikiran lain datang dari Prof. Sri-Edi Swasono dengan pemikiran-pemikiran strukturalisme, walaupun ia lebih banyak menggunakan istilah "Demokrasi Ekonomi". Dengan tema Demokrasi Ekonomi dan Ekonomi Kerakyatan, sumbangan pemikiran dilakukan pula secara substantif oleh Prof. Sritua Arief. Pemikir inilah yang banyak membahas isu-isu kontemporer Ekonomi

${ }^{6}$ Dua tulisan Emil Salim yang berjudul "Sistem Ekonomi Pancasilä. Pertama dimuat di harian Kompas, 30 Juni, 1966 dan kedua dimuat di jurnal Prisma No. 5, Mei 1979.

${ }^{7}$ Lihat makalah-makalah dalam seminar FE-UGM, 19 September, 1980 yang berjumlah 19 dimuat dalam buku Mubyarto \& Budiono "Ekonomi Pancasila", Badan Penerbit FEUGM, Yogyakarta, 1980.

'Baca misalnya "Demokrasi Ekonomi : Keterkaitan Usaha Partisipatif VS Konsentrasi Ekonomi", Dekopin 1989. Pemikirannya yang lebih konpreherisif di tulisnya dalam "Demokrasi Ekonomi Komitmen dan Pembangunan Indonesia" Pidato Pengukuhan Jabatan Guru Besar dalam IImu Ekonomi, pada fakultas Ekonomi, UI, Jakarta 26 Juni, 1989. 
umat beragama), sosialis (kerakyatan) dan kelompok liberal yang berpengaruh di lingkungan inteketual dan dunia bisnis. ${ }^{14}$ Berbeda dengan pelaksanaan EPS di Jerman, sistem perekonomian di Indonesia, sebagaimana diutarakan oleh Emil Salim, dalam jangka waktu lama, bergerak seperti bandul jam ke kiri (sistem komando) dan kekanan (sistem pasar bebas). Dalam gerak bandul jam itu, mula-mula berkembang sistem liberal dengan tekakan keras dari kelompok sosialis, kemudian sejak 1957 bergerak kearah nasionalisme ekonomi yang kemudian berkembang menjadi sistem ekonomi komando yang telah mencapai posisi dominan kemudian mengalami kegagalan karena inflasi. Pada masa Orde Baru, sejak 1967 sistem pasar bebas berkembang kuat sehingga melahirkan sektor swasta yang makin kuat walaupun kekuatan ekonomi yang dominan masih sektor negara, tetapi pada tahun 1997 juga mengalami kegagalan dan berakhir dengan krisis.

\section{Tantangan SEP}

Dilema SEP sekarang sebenarnya indonesia berada di simpang jalan. Sejak tahun 1983, perekonomian mengalami proses liberalisasi, terutama di sektor moneter dan baru terbatas di sektor riil. Tapi pada masa reformasi, di bawah tekanan IMF, terjadi proses liberalisasi di sektor riil, di samping sektor moneter yang terus berjalan, ditandai dengan UU Bank Indonesia yang menetapkan independensi Bank Sentral. Di atas itu pada masa reformasi ini, perekonomian sangat dipengaruhi oleh faham Neo-Liberal. Namun struktur ekonomi yang didukung oleh sektor negara relatif masih cukup kuat, walaupun sektor negara ini mengandung banyak kelemahan dan persoalan, sehingga berada dalam situasi "under attack" (dikritik terus menerus).
Di bawah tekanan pengaruh paham Neo_Liberalisme, pada tahun 2002 timbul usaha-usaha untuk menggantikan seluruh pasal-pasal ekonomi dalam UUD 1945, yang menjadi dasar-dasar SEP. Namun upaya untuk menggantikan pasal 33 dengan sistem ekonomi pasar tidak berhasil, namun telah terjadi penambahan pada pasal 34 dengan pasal-pasal kesejahteraan sosial. Sungguhpun demikian, dengan dihilangkannya penjelasan pasal 33 , maka pasal ini menjadi terkebiri, terutama menyangkut konsep demokrasi ekonomi dan kedudukan koperasi dalam perekonomian nasional. Seandainya telah terjadi penghapusan pasal-pasal ekonomi UUD 1945 tersebut, maka SEP akan kehilangan dasar pijakan, sehingga konsep SEP akan berakhir. Kemungkinan ini masih ada dalam proses reformasi konstitusi yang mungkin saja akan timbul kekuatan yang ingin menggantikan pasal-pasal ekonomi UUD 1945. ${ }^{15}$

Pada tataran praktik, dalam perkembangannya sejak 1950-an dengan interupsi antara tahun 1957-1967, sektor swasta makin kuat, ditandai dengan tumbuhnya perusahaan-perusahaan besar yang menjadi konglomerasi dan grup bisnis besar yang menguasai sektor riil serta masuknya modal asing yang menguasai

${ }^{14}$ Bung Karno dalam tulisannya tahun 1927. "Nasionalisme, Islamisme dan Marxisme" telah mengindentifikasikan tiga kekuatan masyarakat yang sama-sama antiimperialisme. Tapi ia lupa adanya kelompok liberal yang tanda-tandanya sudah muncul páda dasawarsa '30-an, dipelopori oleh St. Takdir Alisyahbana, namun memang baru muncul digelanggang politik sesudah kemerdekaan. Takohnya adalah St. Syahrir, walaupun ia menamakan dirinya "sosialis".

15. Sekarang sudah ada dua lembaga yang mempelajari konstitusi yaitu Mahkamah Konstitusi dan Komite Konstitusi. 
usaha-usaha besar. Tapi sejak 1988, terjadi pertumbuhan bank swasta. Pada masa krisis moneter 1997, sektor perbankan runtuh, namun ditolong oleh Pemerintah melalui program rekapitalisasi dan penyehatan melalui Badan Penyehatan Perbankan Nasional (BPPN). Sebenarnya dengan rekapitalisasi itu, perbankan jatuh ke tangan kontrol pemerintah. Namun akhirakhir ini mengalami privatisasi. Kini berbagai bank swasta nasional terpenting yang menerima Bantuan Likuiditas Bank Indonesia (BLBI), telah terjual kepada modal asing, sehingga saham mayoritas BCA kini telah dikuasai oleh kelompok Farallon dari AS (walapun rumor mengatakan bahwa kelompok "Djarum" , yang core businessnya adalah perusahaan rokok, sebagai berdiri dibelakangnya), padahal semula akan dijadikan sebagai BUMN, karena masih menyandang dana rekapitalisasi. Bank Niaga yang semula dikenal sebagai "bank pribumi" dan dibangun oleh Robby Djohan dengan sukses itu, telah jatuh ke tangan kelompok Asset Commercial Berhad dari Malaysia. Sedangkan Bank Danamon dan Bank Internasional, keduanya dikuasai oleh Grup Temasek, Singapore yang didalamnya terdapat modal Deutsche Bank, Jerman. Grup Temasek ini juga dikenal sebagai pembeli PT. Indosat yang semula merupakan BUMN yang dibanggakan bersama dengan PT. Telkom. Bank Lippo juga jatuh ke tangan pemodal dari Austria (walaupun rumor mengatakan bahwa Muchtar Riady, pemilik lama Lippo, secara informal masih pegang kendali). Tapi berita yang cukup merisaukan adalah rumor tentang rencana untuk menjual $51 \%$ saham Bank BNI. Mengingat pola privatisasi yang terjadi selama ini, diperkirakan Bank BNI akan juga jatuh ke tangan asing. Sebagai upaya legitimasi, baru-baru ini telah muncul tulisan yang mempertanyakan "apakah negara masih perlu menguasai sektor perbankan", padahal selama ini bank-bank BUMN telah berhasil mendominasi sektor perbankan nasional. Arsitektur Perbankan Indonesia (API) yang baru-baru ini dikeluarkan oleh $\mathrm{Bl}$ tidak menyinggung hari depan bank-bank BUMN. ${ }^{16}$

Di bawah bendera globalisasi, dan dalam tekanan kebutuhan penerimaan APBN dan pembayaran hutang luar negeri, telah terjadi proses privatisasi perusahaanperusahaan, khususnya perusahaan besar ke tangan modal asing. Yang menjadi sasaran privatisasi ini adalah BUMN yang kini jumlahnya berkurang dari 240-an menjadi 130-an. Kini telah timbul pertanyaan, bahwa jika masyarakat dan bisnis dunia mampu menyediakan dana investasi dan mampu mengoperasikan perusahaan secara efisien dan menguntungkan, sehingga bisa menjadi sumber perpajakan,' apakah pemerintah masih perlu melakukan investasi dengan pendirian BUMN ? Yang jelas telah terjadi adalah berkurangnya jumlah BUMN, bahkan juga penutupan BUMN-BUMN yang merugi, tidak adanya rencana untuk mendirikan BUMN-BUMN baru dan terus berlangsungnya proses privatisasi, maka sektor negara akan memasuki masa krisis eksistensi dan peranan.

Beberapa faktor obyektif dijadikan argumen dari proses privatisasi ini. Pertama, BUMN dianggap membebani keuangan negara yang cenderung melemah. Kedua, modal asing dinilai sebagai alternatif pembiayaan proyek-proyek yang membutuhkan dana besar. Ketiga, persepsi bahwa perusahaan negara itu tidak efisien

16 Baca Bank Indonesia "Arsitektur Perbankan Indonesia," Jakarta 2004 yang baru saja diterbitkan. 
dan karena itu tidak mampu bersaing di pasar bebas dan pasar global. Keempat, BUMN akan mendesak peranan swasta dalam mengembangkan dunia swasta, karena selalu mendapatkan dukungan dari pemerintah, sehingga menimbulkan "unfairness". Kelima, pandangan bahwa negara sebagai regulator yang adil, tidak bisa merangkap sebagai pelaku bisnis, sebagaimana wasit tidak boleh menjadi pemain dalam sepakbola dan olah raga apapun.

Namun ada argumen yang bisa mendukung eksistensi dan peranan BUMN. Pertama, dalam sistem pasar "bebas", mengapa negara tidak bisa diberi kesempatan untuk menjadi investor, terutama di bidang-bidang tertentu, misalnya industri skala besar, bidang yang menguasai hajat hidup rakyat banyak, industri strategis, bidang-bidang yang swasta tidak tertarik atau bidang-bidang rintisan yang nantinya bisa membuka kesempatan usaha yang lebih luas. Kedua, persepsi bahwa BUMN tidak mampu mencapai efisiensi dan kompetitif, adalah keliru, karena di Singapore umpamanya (dengan contoh Singapore Airline, Singapore Technologies atau Development Bank of Singapore), BUMN bisa berhasil menjadi perusahaan kelas dunia, dan di Indonesiapun terdapat contoh tentang keberhasilan BUMN (misalnya Pupuk Kaltim, Telkom, Semen Gresik, PTP-PTP dsb.). Sebagaimana perusahaanperusahaan swasta yang mampu berkembang karena profesionalisasi, maka BUMN juga bisa melakukan profesionalisasi.

Ketiga, jika negara tidak diperbolehkan melakukan investasi, sementara itu modal nasional makin tipis, maka peluang-peluang investasi besar akan dilakukan oleh kekuatan modal asing yang akan mengambil alih-kedaulatan ekonomi. Keempat, BUMN bisa dicegah untuk mendesak swasta, dengan hanya menangani bidang-bidang yang tidak bisa ditangani oleh swasta atau swasta tidak tertarik, lagi pula BUMN bisa berperan sebagai perintis yang selanjutnya bisa diikuti oleh swasta, bahkan BUMN bisa membantu mengembangkan usaha kecil, menengah dan koperasi. ${ }^{17}$

Masalah kedua yang dihadapi oleh SEP adalah pandangan bahwa koperasi harus merupakan soko-guru perekonomian nasional. Pandangan ini bukannya tidak mungkin dilaksanakan, terbukti dengan koperasi-koperasi di Skandinavia atau koperasi-koperasi pertanian di Belanda, AS, Jepang, Taiwan dan Kanada. Bi Skandinavia, koperasi didukung oleh pemerintah, sedangkan di negara-negara lain koperasi dibiarkan berkembang di pasar. Di Jepang, koperasi dikembangkan oleh Departemen Pertanian, sehingga yang berkembang hanya koperasi pertanian, walaupun berkembang juga di sektor perdagangan, sebagaimana di Singapore.

Di Indonesia, dari periode ke periode, Pemerintah membina koperasi dan akhirnya baru di masa Orde Baru, dibentuk departemen khusus untuk koperasi dan kemudian juga usaha kecil dan menengah. Dari segi kuantitatif, jumlah koperasi cukup besar, pernah mencapai lebih dari 60.000 unit. Koperasi, khususnya Koperasi Unit Desa (KUD) pernah berperan penting dalam pencapaian swasembada beras pada tahun 1985. Namun koperasi- koperasi lain dinilai tidak berkembang, bahkan menjadi sumber $\mathrm{KKN}$ atau diperalat oleh sektor swasta dan negara. Pada dasarnya, koperasi dinilai

${ }^{17}$ Studi mutakhir mengenai privatisasi dan BUMN Indonesia baca A. Effendy Choirie "Privatisasi versus Neo-Sosialisme Indonesia", LP3ES, 2003. 
sebagai sektor yang paling tertinggal dibanding dengan sektor negara dan swasta. Koperasi dinilai tidak mampu bertindak sebagai pelaku bisnis dan hanya berperan sebagai lembaga sosial, itupun dengan kontribusi yang tidak berarti. Kenyataan inilah yang antara lain mendorong usahausaha untuk menghapus asas kekeluargaan untuk diganti dengan asas pasar bebas dalam Amandemen UUD 1945. Jika koperasi gagal berkembang menjadi sokoguru perekonomian, maka SEP akan kehilangan dasar berpijak empiris. Dewasa ini koperasi praktis telah kehilangan kredibilitasnya sebagai badan usaha, apalagi yang juga menyandang "berwatak sosial".

Sungguhpun demikian, hingga saat ini, koperasi masih tetap dipercaya sebagai lembaga ekonomi yang paling cocok untuk mengembangkan usaha kecil dan menengah dan akhir-akhir ini juga di sektor perkreditan. Sebagian besar Bait al Maal wa al Tamwil (BMT) yang sukses berkembang sebagai sebagai lembaga kredit mikro yang tumbuh dari bawah, memakai koperasi sebagai badan hukum dan mekanisme kerja. Koperasi Jasa "Pekalongan" juga merupakan kasus keberhasilan koperasi menjadi koperasi kredit yang beroperasi sesuai prinsip-prinsip perbankan. Di Surabaya juga didapatkan koperasi Setia Bhakti Wanita, yang berkembang menjadi lembaga perkreditan yang sukses dan terus berkembang. Demikian pula tidak sedikit koperasi yang berhasil, misalnya, koperasikoperasi karyawan. Berbagai rencana pengembangan, misalnya pengembangan koperasi nelayan atau koperasi peternakan, masih terus menjadi pilihan. Sungguhpun begitu kasus-kasus keberhasilan itu belum mampu mengangkat citra koperasi dalam perkembangan ekonomi.

Dalam kebijaksanaan ekonomi yang selalu mengacu kepada UUD 1945 dan dengan demikian dapat disebut sebagai SEP, justru sektor swasta yang dianggap berhasil. Indikatornya antara lain, pertama, menghasilkan bagian terbesar dari PDB dan nilai tambah ekonomi nasional. Kedua, berkembangnya lembaga-lembaga badan usaha yang menjadi pelaku-pelaku ekonomi yang produktif dan efisien, sebagian diantaranya, berhasil menjadi perusahaan dan grup perusahaan yang besar. Ketiga, badan-badan perusahaan swasta makin banyak didukung dengan tenaga-tenaga profesional dan memakai teknológi tinggi (penggunaan information technologies). Keempat, perusahaan-perusahaan swasta merupakan sumber pembentukan modal (capital formation) yang makin potensial. Keempat, badan usaha swasta telah menjadi sumber perpajakan yang dewasa ini telah mencapai hampir Rp 800 triliun per tahun. Kelima, sektor swasta telah mampu menjadi motor pertumbuhan ekonomi. Sektor swasta inilah lembaga yang bergerak atas dasar pasar bebas yang kompetitif.

\section{Revitalisasi SEP}

Apakah perkembangan ini dinilai telah menyimpang dari "jalan lurus" SEP ? Dalam arti tertentu, perkembangan sektor swasta, termasuk sektor asing, telah menimbulkan berbagai masalah. Pertama, șektor usaha swasta besar telah menjadi predator terhadap usaha kecil dan menengah, walaupun bisa juga justru menumbuhkan kesempatan baru usaha kecil. Kedua, sektor swasta telah menimbulkan kesenjangan dalam distribusi pendapatan. Ketiga, sektor swasta telah menjadi sumber perilaku bisnis yang tidak etis bahkan menjurus ke ekonomi kriminalitas (crime economy). Keempat, modal asing makin lama makin mendominasi perekonomian nasional. Kelima, sektor swasta terbukti menjadi sumber krisis ekonomi. Keenam, sektor 
swasta menjadi perusak lingkungan hidup, yang jika dinilai dengan biaya, maka tingkat pertumbuhan ekonomi menjadi negatif. Ketujuh, sektor swasta telah menciptakan hutang luar negeri yang besar, melebihi hutang pemerintah. Gejala itu semua bertentangan dengan aksiologi SEP.

Para penganjur EP berpendapàt bahwa berbagai masalah tersebut di atas diakibatkan oleh penyimpanganpenyimpangan pada tingkat kebijaksanaan pembangunan. Karena itulah maka penganjur EP menyerukan untuk "kembali ke khittah" atau kembali menempuh "jalan lurus" yang menurut Emil Salim adalah SEP. Guna meyakinkan telah terjadinya penyimpangan-penyimpangan atau belum dilaksanakannya SEP, maka diperlukan suatu studi untuk menilai produk perundangundangan dari waktu ke waktu, yaitu misalnya: UU Penanaman Modal Asing (PMA), UU Penanaman Modal Dalam Negeri (PMDN), UU Pokok Agraria, UU Perbankan, UU Bank Indonesia, UU Pokok Koperasi, UU BUMN, UU Perseroan Terbatas, UU Pertambangan, UU Perburuhan, apakah UU itu telah melaksanakan prinsip-prinsip SEP ataukah telah terjadi penyimpangan. Perlu pula dikaji berbagai Ketetapan MPRS dan MPR. TAP MPR No. XXIII/MPRS/1966 umpamanya, menyatakan dirinya sebagai implementasi SEP yang dilaksanakan dalam pembangunan Orde Baru. Tapi pembangunan Orde Baru juga melakukan penyimpangan-penyimpangan, sehingga diperlukan reformasi ekonomi.

Di alam reformasi sekarang ini, pengembangan BUMN dan koperasi menghadapi persoalan. BUMN harus berhadapan dengan arus globalisasi yang berujud privatisasi. Koperasi juga menghadapi masalah karena telah kehilangan kredibilitas sebagai badan usaha yang efisien dan bersih dari KKN. Komponen
SEP yang masih bertahan adalah Ekonomi Kerakyatan (EK). Komponen kerakyatan dewasa ini masih mendapatkan angin karena pertama, ambruknya usaha besar dan konglomerasi, sehingga bank-bank tidak lagi berani mengucurkan kredit. Kedua, bertahannnya UKM terhadap krisis 1997, bahkan justru pada masa krisis itu lahir UKM-UKM baru. Ketiga, gelombang kebangkitan kembali UKM di tingkat global, dimulai di Itali dan AS, demikian juga telah bangkit di beberapa negara Eropa Barat, Taiwan, Korea Selatan, RRC dan Thailand. Dalam kebangkitan itu Bank Dunia makin menaruh perhatian terhadap potensi perkembangan UKM.

Pertanyaan yang timbul adalah, apakah UKM dapat menarik manfaat dari globalisasi? Joseph Stiglitz umpamanya, percaya bahwa globalisasi bisa membantu mengatasi'kemiskinan asal dikelola secara benar, tidak sebagaimana dilakukan oleh IMF. ${ }^{18}$ Menurut pandangan yang optimis, UKM justru akan bisa memanfaatkan sumberdaya global, antara lain teknologi informasi. Melalui teknologi informasi, produk-produk UKM yang memiliki kekhasan, bisa dipasarkan di tingkat global, tanpa melalui perusahaan-perusahaan besar. Selain itu, dengan berkembangnya sistem outsourcing dewasa ini, banyak pekerjaan akan diserahkan kepada UKM di negara-negara sedang berkembang.

Di lain pihak produk-produk usaha besar (UB) skala global telah menyingkirkan produk-produk lokal. Dalam skala besar, produk-produk usaha besar itu mampu

${ }^{18}$ Joseph E. Stiglitz "Globalization and its Discontents" W.W. Norton Company, N.Y, London, 2002. Baca hal 4 dan 5. Disamping menjanjikan mengatasi kemiskinan, ternyata globalisasi dalam pengamatan Stiglitz juga telah menciptakan kemiskinan baru. 
menghasilkan produk-produk berkualitas dengan harga yang murah. Produk-produk pertanian, khususnya pangan, dari negaranegara besar, telah menjatuhkan harga produk-produk pertanian. Sementara itu, pemerintah negara-negara sedang berkembang tidak diperbolehkan untuk melakukan proteksi pasar dan memberi subsidi yang amat besar. Bersamaan dengan itu, sektor pertanian di negara-negara maju sendiri mendapatkan subsidi yang besar dan proteksi pasar. Ini menimbulkan ketidakadilan (unfairness) dalam praktik globalisasi yang didominasi oleh kepentingan negara-negara industri maju.

Dalam proses industrialisasi, negaranegara sedang berkembang, termasuk Indonesia menghadapi dilema di bidang permodalan. Di satu pihak, dianggap menguntungkan untuk memanfaatkan modal dari luar negeri, karena ketersediaan maupun murahnya harga modal. Lagi pula modal asing selalu didukung dengan teknologi dan penguasaan pasar. Di lain pihak jika memanfaatkan dengan mengundang modal asing, maka perekonomian dapat didominasi oleh modal asing, sehingga rakyat hanya akan menjadi kuli. Secara ekonomi, Indonesia akan menjadi negara jajahan kembali.

\section{Penutup}

Peranan negara juga mengandung dilema. Agar bisa berperan kuat, maka negara harus menguasai modal atau dana. Tetapi dana yang terbaik adalah yang bersumber dari pajak. Sebab, pajak akan meningkatkan demokrasi. Namun untuk bisa menarik pajak, harus dikembangkan usaha-usaha, terutama usaha-usaha swasta. UB dan perusahaan asing akan bisa membayar pajak lebih baik. Karena itu, maka pemerintah terdorong untuk mengembangkan usaha swasta dan memberi kesempatan pada modal asing. Guna mengembangkan swasta, diperlukan sistem pasar bebas.

Berdasarkan pengalaman pelaksanaan EPS di Jerman, pengembangan sistem pasar bebas tidak menjadi persoalan asalkan; pertama, diatur dengan hukum yang kuat. Kedua, dikontrol oleh pemerintah yang kuat dan independen. Ketiga, diimbangi dengan kebijaksanaan sosial yang mencakup aspek distribusi pendapatan dan kekayaan, jaminan sosial dan perlindungan terhadap tenaga kerja.

\section{Daftar Pustaka}

Alfaruqiy, M. Furqon \& M. Soelhi eds.1995, Relevansi Ekonomi Pasar Sosial bagi Indonesia, Jakarta: CIDES \& Konrad Adenaurer-Stiftung.

Arief, Sritua, 1998, Pembangunanisme dan Ekonomi Indonesia: Pemberdayaan Rakyat dalam Arus Globalisasi, Zaman.

Bank Indonesia 2004, Arsitektur Perbankan Indonesia, Jakarta.

Basyaib, Hamid dan Hamid Abidin eds. 2000, Kembali ke Jalan Lurus: Esaiesai 1966-99, Jakarta: Alvabet.

Choirie, A. Effendy 2003, Privatisasiversus Neo-Sosialisme Indonesia, Jakarta: LP3ES.

Jung, Cel. Winfried, Social Market Economy: an Economic System for Developing Countries. Internationales Institut Konrad Adenauer-Stiftung.

Mubyarto dan Budiono 1980 Ekonomi Pancasila, BPFE UGM, Yogyakarta. 
Isu-isu Kontemporer Ekonomi Pancasila; M. Dawam Rahardjo

Mubyarto, 2000, Membangun Sistem Ekonomi Yogyakarta: BPFE.

Salim, Emil, 1965, Sistem Ekonomi dan Ekonomi Indonesia Lembaga Ekonomi dan Kemasyarakatan Nasional, Jakarta: Majelis IImu Pengetahuan Indonesia.

"Sistem Ekonomi Pancasila".

Kompás, 30 Juni, 1966, Jakarta. "Sistem Ekonomi Pancasila".

Prisma No. 5, Mei 1979, Jakarta.
Stiglitz, Joseph E., 2002, Globalization and its Discontents London: W.W. Norton Company.

Suwarsono, Sri Edi, 1989, "Demokrasi Ekonomi Komitmen dan Pembangunan Indonesia", Pidato Pengukuhan Jabatan Guru Besar dalam Ilmu Ekonomi, pada fakultas Ekonomi, UI, Jakarta. 